\title{
ELECTRO-ANTENNOGRAPHIC RESPONSE OF HELOPELTIS THEIVORA TO SYNTHETIC PESTICIDES USED IN TEA PLANTATIONS
}

\author{
KokKadan K. SRikumar, * SuKumaran SMitha, \\ BASTIAN S. KUMAR and BALAKRISHNAN RADHAKRISHNAN \\ UPASI Tea Research Institute, Valparai, Coimbatore Tamil Nadu 642 127, India
}

(Received: January 26, 2017; accepted: July 11, 2017)

\begin{abstract}
Helopeltis theivora is considered as one of the major pest in tea plantations causing considerable economic damage. Recent control strategies against this notorious polyphagous pest mainly depend on the application of insecticides. The study is focused on the antennal response of $H$. theivora on exposure to different insecticides using electroantenogram (EAG). The result showed that the insects perceive quinalphos as they are frequently exposed to it. The hierarchy of the EAG response of exposed and unexposed insects was quinalphos $>$ bifenthrin $>$ deltamethrin $>$ thiamethoxam.
\end{abstract}

Keywords: Electroantenogram - Helopeltis theivora - insecticide - polyphagous

\section{INTRODUCTION}

Camellia sinensis (L.) O. Kuntze is a perennial, monoculture crop and forms an ideal habitat providing constant and continuous food supply to a wide range of pest species. Tea industry plays a pivotal role in the economy of India by providing job opportunity to millions of people, besides adding appreciable amount of foreign exchange to our country's exchequer [8]. The tea plantations with the adjoining forest areas contribute a to the sustenance of terrestrial ecosystem by providing extensive land cover with diverse species of organisms. Such monoculture habitat of the tea crop becomes so conductive for the perpetuation of arthropods in general and insect pests in particular [12].

Tea mosquito bug (TMB), Helopeltis theivora Waterhouse (Hemiptera: Miridae) has assumed considerable significance in the last few years due to its widespread occurrence in Vandiperiyar, Peermade (Kerala) and Valparai (Tamil Nadu) [17]. Helopeltis theivora is usually considered as wet weather pest, but recently the change in agro climatic conditions resulted in occurrence of this pest throughout the year and thus causing huge economic damage to tea industry. Prior to the use of modern chemical pesticides, crop losses on tea plantations in India sometimes reached 100

\footnotetext{
*Corresponding author; e-mail address: sreeku08@gmail.com
} 
percent [12].The presence of $H$. theivora on tea was documented in India more than a century ago $[15,26]$. Its outbreak was reported in southern part of India in around 1920 [18]. It infests tea plantation, laying their eggs safely inside the tea plant stems and thus well protected so that it can survive all the odd circumstances. The adult and younger stages of the bugs make punctures on the tea leaves and while sucking the sap, the bugs inject toxic saliva into the leaf resulting in the formation of punctures, wart like structures and discoloration of the leaves. The excess feeding by nymphs and adults, makes the leaves curl up and badly deformed, drying up of the young shoots leading to the loss of entire crop [19, 20, 22, 23].

There are several synthetic pesticides used on tea plantation to control this bug; that is the only means to control this pest at present. However, they leave harmful residues; alter the properties like taint, strength of liquor and taste of the tea etc. A decrease in the effectiveness of lindane against $H$. theivora on tea in the Cachar region of India was reported by Muraleedharan [12] and similar signs of resistance have been noted for the same species on cocoa in Malaysia [2]. Due to the development of resistance usually quick reinfestation of the pest occur, and the need and cost of continually engineering new pesticides increases. In recent year's quinalphos, thiamethoxam, thiacloprid, bifenthrin, deltamethrin and clothianidin which are registered in Plant Protection Code Version VII of Tea Board (http://www.teaboard.gov.in/ pdf/Plant_Protection_Code_Ver_7_0_September_2016_pdf3785.pdf) (Accessed 17 Nov., 2016) are recommended for $H$. theivora control in South India.

Even after frequent usage of these insecticides, there is no relief against $H$. theivo$r a$ infestation in tea [16]. It is extremely important to investigate the behavioral aspects of $H$. theivora against these insecticides. The electroantenogram (EAG) can register responses to wide varieties of odorants. Although it has been successfully employed for pheromone identifications over the years; it is now increasingly being used for identifying host-odor volatiles important to behaviors such as attraction [3, 9]. We evaluated the EAG responses of nymph, male and female $H$. theivora to different insecticides applied in tea plantations.

\section{MATERIALS AND METHODS}

Random field surveys were conducted from December 2014 to November 2015 in the conventional tea plantations of Anamallais $\left(10^{\circ} 22^{\prime} \mathrm{N}\right.$ latitude, $76^{\circ} 58^{\prime} \mathrm{E}$ longitude and $1065 \mathrm{~m}$ a. s. 1) Tamil Nadu, South India to gather information on the pesticide usage against $H$. theivora. A total of 34 tea estates were surveyed. The managers of the respective estates where asked for PPC Version VII recommended insecticides they use against $H$. theivora. The data obtained were tabulated in percentage at monthly interval.

Helopeltis theivora males and females collected from the conventional insecticide treated fields and from organic fields were brought to the laboratory. The rearing was done in laboratory at $25 \pm 1{ }^{\circ} \mathrm{C}$ and $12 \mathrm{~L}$ : $12 \mathrm{D}$ photoperiod. Insect culture from conventional and organic fields was maintained separately. The $H$. theivora nymphs and 


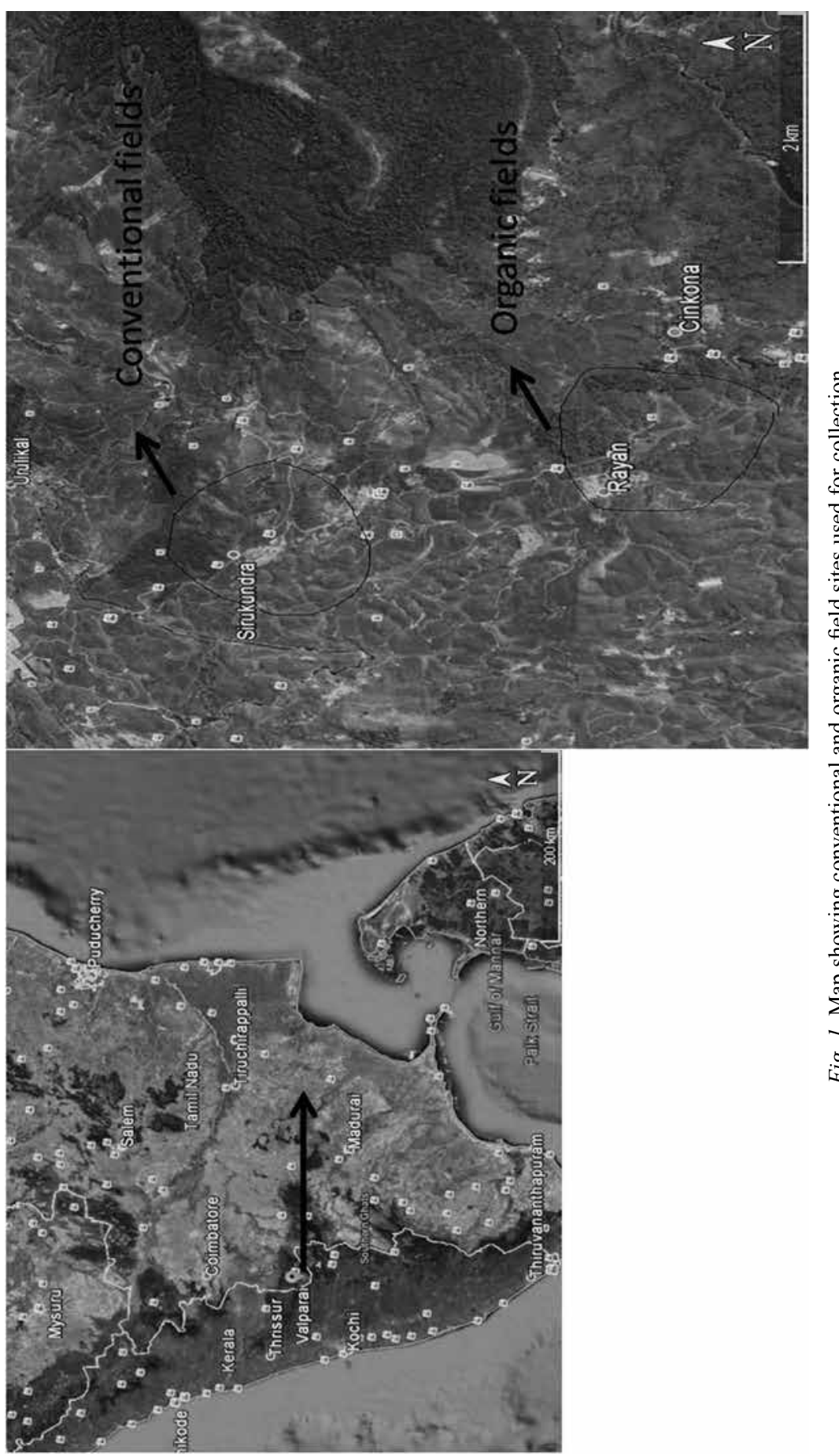

Acta Biologica Hungarica 68, 2017 
adults collected from conventional fields are termed as 'exposed' and from organic fields are termed as 'unexposed' (Fig. 1). Females and males were released in transparent jars $(25.5 \mathrm{~cm} \times 11 \mathrm{~cm})$ with nylon mesh sleeve. Seven to ten tea shoots each of three leaves and a bud were wrapped together with wet cotton and inserted tightly into a glass vial $(5 \mathrm{~cm}$ long $\times 2.5 \mathrm{~cm}$ wide $)$ were kept inside each jar. Nymphs collected from the field were introduced into separate jars. Every alternate day, the vials were replaced with fresh shoots, and nymphs and adults were carefully released. After adult emergence they were sexed, paired and released into separate jars. Only F1 progeny insects were used for the experiments.

Electroantennogram (EAG) measures micro voltage fluctuation between the tip and base of the antenna during the stimulus application by amplifying the signal (change in voltage). Fifth instar nymphs, males and females were anesthetized with $\mathrm{CO}_{2}$ for $5 \mathrm{~s}$, the head was clipped off, and the antenna was excised under a microscope. The basal segment of the antenna was cut off and inserted into the ground electrode, and the recording electrode was sleeved over the tip of the antenna. The insecticides tested against $H$. theivora were Quinalphos 25 EC (Ekalux, Syngenta India Lim.) -2 ml/l; Bifenthrin 8 SC (Brigade, Danuka Agritech Lim.) $-1 \mathrm{ml} / 1$; Deltamethrin 2.8 EC (Decis, Bayer Crop Science Lim.)-1 ml/1; Thiamethoxam 25 WG (Actara, Syngenta India Ltd.) $-0.2 \mathrm{~g} / \mathrm{l}$. Quinalphos was tested at different doses $(30 \mu \mathrm{l}, 50 \mu, 100 \mu \mathrm{l}$ and $150 \mu \mathrm{l})$ to females, males and fifth instar nymphs of exposed $H$. theivora. This was conducted to determine the optimum dose for the experiment.

Physical properties of the tested insecticide are presented in the Table $1.100 \mu 1$ of each insecticide was used as testing dose. Odor presentation was similar to that of previous studies $[6,7,14,24]$ of each insecticide was applied to a piece $(5 \times 60 \mathrm{~mm})$ of filter paper (Whatman ${ }^{\circledR}$, No. 4 ash less) which was then inserted into a glass

Table 1

Physical properties of tested Insecticides

\begin{tabular}{|l|c|c|c|c|}
\hline \multicolumn{1}{|c|}{ Insecticide } & Quinalphos & Bifenthrin & Deltamethrin & Thiamethoxam \\
\hline Chemical formula & $\mathrm{C}_{12} \mathrm{H}_{15} \mathrm{~N}_{2} \mathrm{O}_{3} \mathrm{PS}$ & $\mathrm{C}_{23} \mathrm{H}_{22} \mathrm{C}_{1} \mathrm{~F}_{3} \mathrm{O}_{2}$ & $\mathrm{C}_{22} \mathrm{H}_{19} \mathrm{Br}_{2} \mathrm{NO}_{3}$ & $\mathrm{C}_{8} \mathrm{H}_{10} \mathrm{CIN}_{5} \mathrm{O}_{3} \mathrm{~S}$ \\
\hline Mol. Wt & 298.3 & 422.9 & 505.2 & 291.7 \\
\hline Form & $\begin{array}{c}\text { Colorless } \\
\text { crystals }\end{array}$ & $\begin{array}{c}\text { Viscous liquid; crystal- } \\
\text { line or waxy solid }\end{array}$ & Colorless crystals & $\begin{array}{c}\text { Crystalline } \\
\text { powder }\end{array}$ \\
\hline Melting point & $31-32^{\circ} \mathrm{C}$ & $68-70.6^{\circ} \mathrm{C}$ & $100-102{ }^{\circ} \mathrm{C}$ & $139.1{ }^{\circ} \mathrm{C}$ \\
\hline Vapor pressure & 0.346 & $1.7810^{-3} \mathrm{mPa}$ & $1.2410^{-5} \mathrm{mPa}$ & $6.610^{-6} \mathrm{mPa}$ \\
\hline Solubility in water & $17.8 \mathrm{mg} / 1$ & $<1 \mu \mathrm{g} / 1$ & $<0.2 \mu \mathrm{g} / 1$ & $4.1 \mathrm{~g} / 1$ \\
\hline Stability & $\mathrm{Stable}$ & Stable for 2 years & $\begin{array}{c}\text { Extremely stable } \\
\text { on exposure to air }\end{array}$ & Stable at pH 5 \\
\hline DT $_{50}$ & $39 \mathrm{~d}(\mathrm{pH} 6)$ & $255 \mathrm{~d}$ & $31 \mathrm{~d}$ (pH 8) & $640 \mathrm{~d}(\mathrm{pH} 7)$ \\
\hline
\end{tabular}


Pasteur pipette ( $15 \mathrm{~cm}$ long). The tip of the glass pipette was inserted about $3 \mathrm{~mm}$ into a small hole in the wall of a stainless steel tube (15 mm diameter, $15 \mathrm{~cm}$ long) directed over the antennal preparation. An air stimulus controller (model CS-05b; Syntech ${ }^{\circledR}$, Hilversum, The Netherlands) was used for air and odor delivery with a constant air flow $(240 \mathrm{ml} / \mathrm{min})$. Charcoal-filtered and humidified air was passed over the antenna through the open end of the glass tube positioned $15 \mathrm{~mm}$ from the antenna. During odor stimulation, $1 \mathrm{ml} / \mathrm{min}$ of air was applied through the Pasteur pipette into the main air flow for $1 \mathrm{~s}$. At least 2-mn intervals were maintained between stimulations which were made in order of insecticides. The EAG response to a standard stimulus, Hexen-1-ol (that evoked detectable EAG but is chemically unrelated to those insecticides), were recorded first and then again after every five recordings. The mean of two EAG responses to the standard was used for normalization of the responses to the test insecticides recorded between them. A two-factor randomized complete block analysis of variance (ANOVA) was conducted on the EAG data followed by Least Significance Difference (LSD) at the 5\% level of significance using SPSS 22 Software [10].

\section{RESULTS}

A total of four insecticides were found widely used against $H$. theivora in tea plantations. Quinalphos was the most effective and common pesticide used in tea plantations. Bifenthrin and deltamethrin which are synthetic pyrethriods were the second and third most prevalent type of pesticides used. This was followed by thiamethoxam which is a neonicotinoid (Fig. 2). The usage of quinalphos was higher particularly

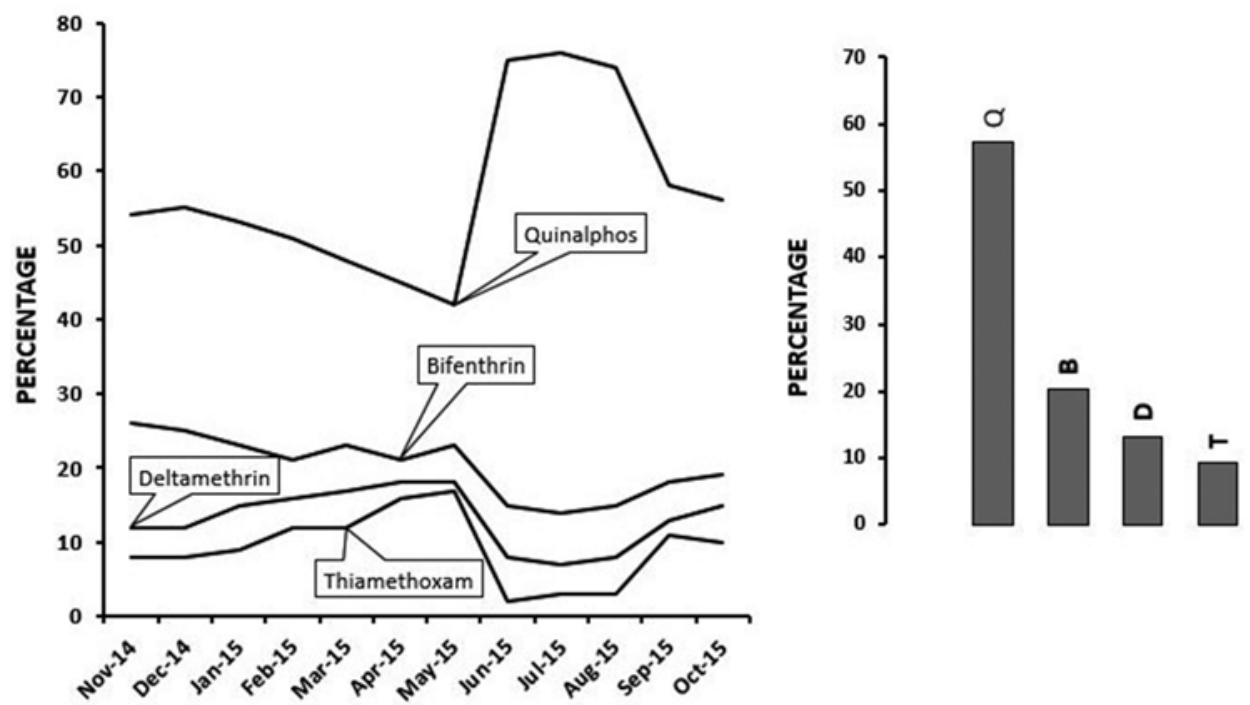

Fig. 2. Pesticide usage against Helopeltis theivora in tea plantations during 2014-2015 Q - Quinalphos; B - Bifenthrin; D - Deltamethrin; T - Thiamethoxam 


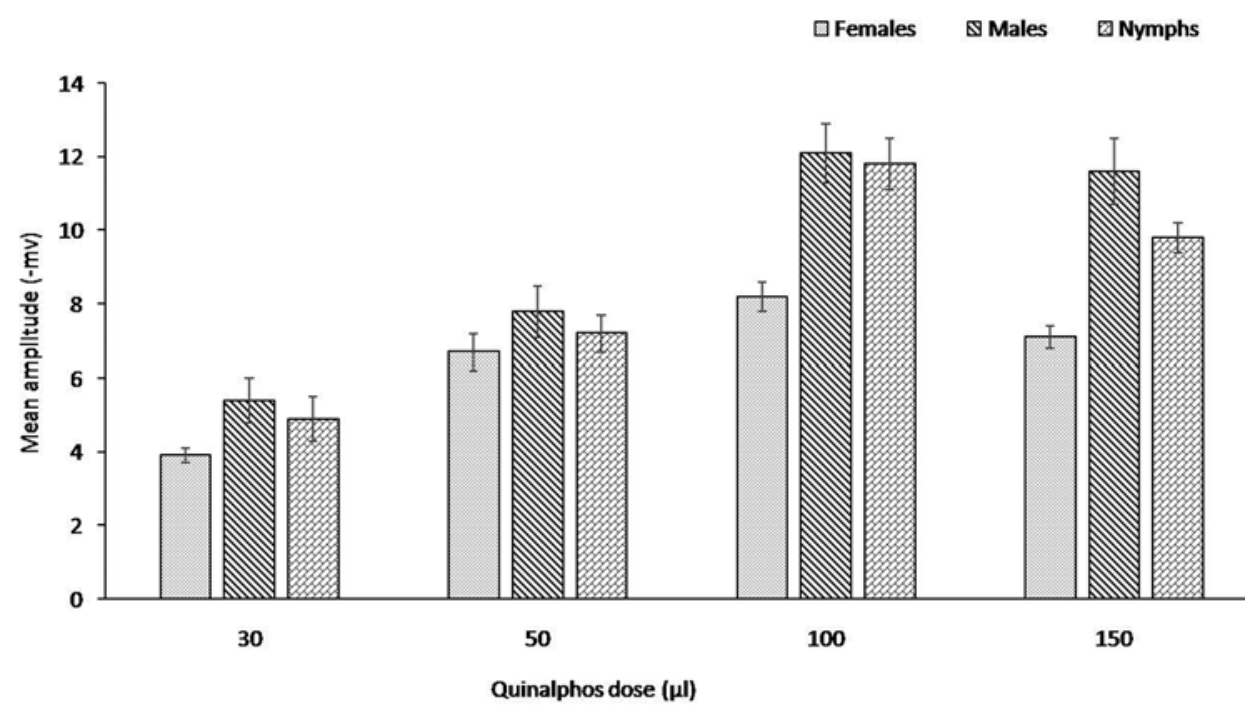

Fig. 3. Dose-response curve constructed from EAGs of female, male and nymph of $H$. theivora exposed to Quinalphos

during monsoon season (June to September). The dose-response curves indicated that $100 \mu \mathrm{l}$ of Quinalphos showed higher antennal response to females, males and nymphs of exposed H. theivora (Fig. 3).

Electroantennogram response of $H$. theivora exposed and unexposed fifth instar nymphs, males, and females showed difference in perception of the tested insecticides. The life stages of exposed and unexposed $H$. theivora were highly sensitive to quinalphos followed by bifenthrin, deltamethrin and thiamethoxam. The exposed fifth instar nymphs exhibited a mean response of $11.8 \pm 0.3 \mathrm{mV}$ and $11.2 \pm 0.2 \mathrm{mV}$ towards quinalphos $(100 \mu \mathrm{l})$ and bifenthrin $(100 \mu \mathrm{l})$, respectively. These responses were significantly $(p \leq 0.05)$ superior to deltamethrin $(100 \mu \mathrm{l})(9.3 \pm 0.2 \mathrm{mV})$ and thiamethoxam $(100 \mathrm{mg})(6.7 \pm 0.2 \mathrm{mV})$. Unexposed fifth instar nymphs showed significantly $(p \leq 0.05)$ higher EAG response to quinalphos $(3.2 \pm 0.1 \mathrm{mV})$ than to bifenthrin $(2.3 \pm 0.1 \mathrm{mV})$, deltamethrin $(2.0 \pm 0.1)$ and thiamethoxam $(1.5 \pm 0.1)$. Responsiveness was significantly $(p \leq 0.05)$ higher for exposed fifth instar nymphs than unexposed nymphs to quinalphos, bifenthrin, deltamethrin and thiamethoxam (Table 2).

Helopeltis theivora male sensitiveness also varied to all the tested insecticides. Exposed males were found to be significantly $(p \leq 0.05)$ sensitive to the insecticides than to unexposed. EAG amplitude was $12.1 \pm 0.1 \mathrm{mV}$ towards quinalphos, which was significantly $(p \leq 0.05)$ higher than bifenthrin $(9.8 \pm 0.1 \mathrm{mV})$, deltamethrin $(8.3 \pm 0.3)$ and thiamethoxam $(6.3 \pm 0.6)$ in exposed males. For unexposed males, the response was significantly $(p \leq 0.05)$ high for quinalphos than to bifenthrin, deltamethrin and thiamethoxam. Response was on par for bifenthrin, deltamethrin and thiamethoxam (Table 3). 
Table 2

EAG response of exposed and unexposed nymphs against insecticides

\begin{tabular}{|l|c|c|}
\hline \multirow{2}{*}{ Insecticides } & \multicolumn{2}{|c|}{$\begin{array}{c}\text { Helopeltis theivora } \text { nymphs response } \\
\text { (Amplitude mV) }\end{array}$} \\
\cline { 2 - 3 } & Exposed & Unexposed \\
\hline Quinalphos & $11.8 \pm 0.3 \mathrm{Aa}$ & $3.2 \pm 0.1 \mathrm{Ba}$ \\
\hline Bifenthrin & $11.2 \pm 0.2 \mathrm{Ab}$ & $2.3 \pm 0.1 \mathrm{Bb}$ \\
\hline Deltamethrin & $9.3 \pm 0.2 \mathrm{Ac}$ & $2.0 \pm 0.1 \mathrm{Bbc}$ \\
\hline Thiamethoxam & $6.7 \pm 0.2 \mathrm{Ad}$ & $1.5 \pm 0.1 \mathrm{Bcd}$ \\
\hline Hexen-1-ol & $4.2 \pm 0.1$ & $3.9 \pm 0.5$ \\
\hline
\end{tabular}

The means $( \pm \mathrm{SE})$ in the same column followed by the same letters in lowercase are not significantly different at $p \leq 0.05$ (LSD, SPSS 22); the same letters in uppercase in the same row are not significantly different at $p \leq 0.05$ (LSD, SPSS 22).

Table 3

EAG response of exposed and unexposed males against insecticides

\begin{tabular}{|l|c|c|}
\hline \multirow{2}{*}{ Insecticides } & \multicolumn{2}{|c|}{$\begin{array}{c}\text { Helopeltis theivora males response } \\
\text { (Amplitude } \mathrm{mV} \text { ) }\end{array}$} \\
\cline { 2 - 3 } & Exposed & Unexposed \\
\hline Quinalphos & $12.1 \pm 0.1 \mathrm{Aa}$ & $5.2 \pm 0.3 \mathrm{Ba}$ \\
\hline Bifenthrin & $9.8 \pm 0.1 \mathrm{Ab}$ & $3.4 \pm 0.2 \mathrm{Bb}$ \\
\hline Deltamethrin & $8.3 \pm 0.3 \mathrm{Ac}$ & $3.3 \pm 0.1 \mathrm{Bb}$ \\
\hline Thiamethoxam & $6.3 \pm 0.6 \mathrm{Ad}$ & $3.1 \pm 0.8 \mathrm{Bb}$ \\
\hline Hexen-1-ol & $5.3 \pm 0.4$ & $4.6 \pm 0.3$ \\
\hline
\end{tabular}

The means $( \pm$ SE) in the same column followed by the same letters in lowercase are not significantly different at $p \leq 0.05$ (LSD, SPSS 22); the same letters in uppercase in the same row are not significantly different at $p \leq 0.05$ (LSD, SPSS 22).

Table 4

EAG response of exposed and unexposed females against insecticides

\begin{tabular}{|l|c|c|}
\hline \multirow{2}{*}{ Insecticides } & \multicolumn{2}{|c|}{$\begin{array}{c}\text { Helopeltis theivora females response } \\
\text { (Amplitude } \mathrm{mV} \text { ) }\end{array}$} \\
\cline { 2 - 3 } & Exposed & Unexposed \\
\hline Quinalphos & $8.2 \pm 0.3 \mathrm{Aa}$ & $7.8 \pm 1.5 \mathrm{Aa}$ \\
\hline Bifenthrin & $7.5 \pm 0.3 \mathrm{Aab}$ & $4.6 \pm 1.1 \mathrm{Bb}$ \\
\hline Deltamethrin & $6.2 \pm 0.2 \mathrm{Abc}$ & $4.7 \pm 0.4 \mathrm{Ab}$ \\
\hline Thiamethoxam & $5.5 \pm 0.6 \mathrm{Ac}$ & $3.8 \pm 0.1 \mathrm{Ab}$ \\
\hline Hexen-1-ol & $5.7 \pm 0.2$ & $5.3 \pm 0.1$ \\
\hline
\end{tabular}

The means $( \pm \mathrm{SE})$ in the same column followed by the same letters in lowercase are not significantly different at $p \leq 0.05$ (LSD, SPSS 22); the same letters in uppercase in the same row are not significantly different at $p \leq 0.05$ (LSD, SPSS 22). 
The amplitude of EAG response for exposed H. theivora females was less towards insecticides compared to males and fifth instar nymphs. Exposed females showed significantly $(p \leq 0.05)$ higher response to quinalphos $(8.2 \pm 0.3 \mathrm{mV})$ and bifenthrin $(7.5 \pm 0.3 \mathrm{mV})$ than deltamethrin $(6.2 \pm 0.2 \mathrm{mV})$ and thiamethoxam $(5.5 \pm 0.6 \mathrm{mV})$. The exposed females exhibited significantly $(p \leq 0.05)$ higher response to quinalphos than bifenthrin $(4.6 \pm 1.1 \mathrm{mV})$, deltamethrin $(4.7 \pm 0.4 \mathrm{mV})$ and thiamethoxam $(3.8 \pm 0.1 \mathrm{mV})$ (Table 4). In contrast to fifth instar nymphs and males, the response to quinalphos was on par $(p \leq 0.05)$ for exposed and unexposed females.

The present study demonstrates that fifth instar nymphs, males and females of H. theivora responded to the insecticides evaluated in EAG studies, with differences in response observed with quinalphos, bifenthrin, deltamethrin and thiamethoxam. Of the four insecticides tested, $100 \%$ elicited conspicuous EAG responses, mostly as negative deflections about 1.5 to $12.1 \mathrm{mV}$ in amplitude with a time course of 2-3 seconds. The EAG response of $H$. theivora towards the insecticides was coinciding with the frequently used insecticide in tea plantations (Fig. 1).

\section{DISCUSSION}

The hierarchy of the EAG response of exposed and unexposed insects was quinalphos $>$ bifenthrin $>$ deltamethrin $>$ thiamethoxam. This study has clearly shown that H. theivora are capable of detecting insecticides, such as quinalphos, bifenthrin, deltamethrin and thiamethoxam. The influence of environmental factors, such as the continuous use of insecticides and the chemical constituents (allelochemicals) of host plants, in the case of phytophagous insects can have a great impact on inducing the enzymatic detoxification systems of insects, thereby affecting insecticide resistance mechanisms $[27,28,39]$. These kinds of behavioral modifications in animals are assumed to be the result of complex processes in the brain [1]. Physical properties of the insecticides (e.g., volatility) also can be factors involved in their repellency. By definition, repellency can occur only if stimuli are perceived from a distance without contact, so the compound needs to be in vapor phase [11].

The amplitude of depolarization has been used to measure the sensitivity of insects to volatile compounds. Differences observed, particularly in males, with respect to relatively longer durations for depolarizations and recovery to baseline is probably due to deactivation processes of the receptor site [4]. It reflects that several of the molecules evaluated, viz., quinalphos, bifenthrin, deltamethrin and thiamethoxam bind to the receptor sites of olfactory neurons of antennal sensilla which may have an effect on the behaviour of $H$. theivora. The ability of nymphs, males and females to detect the odours presented is probably due to their similar habitat requiring the use of the same cues to locate host plants for survival and reproduction. The hierarchy of responses was greater for the exposed males, nymphs and females than the unexposed.

Among the sexes, the response of males to all the compounds tested was higher as compared to the females. The present study strongly agrees that the difference in the 
physical property between males and females may be the cause for the lower amplitude of EAG recorded in females as compared to males [21]. Study on antenna of cotton bollworm moths (Helicoverpa armigera, Hubner) (Lepidoptera: Noctuidae) subjected to 15 insecticides, showed that the EAG response varied significantly with sex. EAG responses of females were lower than that of males [25]. It was also documented that $H$. theivora male population showed higher level of resistance than females [5].

Our study also revealed that the EAG response of exposed and unexposed $H$. theivora varied. The exposed insects showed high response to insecticides when compared to unexposed. The development of resistance in H. theivora towards commonly used insecticides may be attributed due to repeated application of the same insecticide and mixing of different groups of insecticides [5].

\section{CONCLUSIONS}

Many aspects of the responses, both behavioral and electrophysiological of $H$. theivo$r a$ to pheromones have been extensively studied and are probably better known than for any other species of Helopeltis. However, the responses of the H. theivora to frequently applied chemical insecticides have received much less attention. The life stages of $H$. theivora were capable of detecting the frequent chemical insecticides applied in tea plantations. The exposed insects showed high response to insecticides when compared to unexposed. This study has clearly shown that $H$. theivora are capable of detecting the commonly used insecticides in tea plantations.

\section{ACKNOWLEDGEMENT}

The authors extend their thanks to Dr. S. Kannan, Head- R \& D, Barrix Agro Sciences Pvt. Ltd. for the help rendered in electroantenogram (EAG) studies.

\section{REFERENCES}

1. Alcock, J. (1984) Animal Behaviour: an evolutionary approach, $3^{\text {rd }}$ edition, Sinauer Associates Sunderland, Mass.

2. Chong, K. K. (1987) The cocoa mirid in Peninsular Malaysia and its management. Planter 63, $16-520$.

3. Cork, A. (1994) Identification of electrophysiologically-active compounds for New World screw worm, Cochliomyia hominivorax, in larval wound fluid. Med. Vet. Entomol. 8, 151-159.

4. Dickens, J. C., Gutman, A., Payne, T., Ryker, L. C., Rudinsky, J. A. (1983) Antennal olfactory responsiveness of Douglas fir beetle, Dendroctonus psuedosugae Hopkins (Coleoptera: Scolytidae) to pheromones and host odors. J. Chem. Ecol. 9, 1383-1395.

5. Gurusubramanian, G., Bora, S. (2007) Relative toxicity of some commonly used insecticides against adults of Helopeltis theivora Waterhouse (Miridae: Hemiptera) collected from Jorhat area tea plantations, South Assam, India. Resistant Pest Manag. Newsl. 17, 8-12. 
6. Han, B. Y., Chen, Z. M., Fang, Y. L. (2001) Electrophysiology and behavior feedback of diamond back moth, Plutella xylostella, to volatile secondary metabolites emitted by Chinese cabbage. Chinese Sci. Bull. 46, 2086-2088.

7. Han, B. Y., Chen, Z. M. (2002) Behavioral and electrophysiological responses of natural enemies to synomones from tea shoots and kairomones from tea aphids, Toxoptera aurantii. J. Chem. Ecol. 28, 2203-2219.

8. Hazarika, L. K., Bhuyan, M., Hazarika, B. N. (2009) Insect pests of tea and their management. Annu. Rev. Entomol. 54, 267-284.

9. Honda, K., Omura, H., Hayashi, N. (1999) Identification of floral volatiles from Ligustrum japonicum that stimulate flower-visiting by cabbage butterfly, Pierisrapae. J. Chem. Ecol. 24, 2167-2180.

10. IBM Corp. (2013) IBM SPSS Statistics for Windows, Version 22.0. IBM Corp Armonk, NY.

11. Miller S. L., Haber, W. A., Setzer, W. N. (2009) Chemical composition of the leaf essential oil of Casimiroa edulis La Llave\&Lex. (Rutaceae) from Monteverde, Costa Rica. Nat Prod Commun. 4, 425-426.

12. Muraleedharan, N. (1987) Entomological research in tea in Southern India. J. Coffee Res. 17, 80-83.

13. Muraleedharan, N. (1992) Bioecology and management of tea pests in southern India. J. Plant. Crops. 20, 1-21.

14. Park, K. C., Elias, D., Donato, B., Hardie, D. J. (2000) Electroantennogram and behavioural responses of different forms of the bird cherry-oat aphid, Rhopalosiphum padi, to sex pheromone and plant volatiles. J. Insect Physiol. 46, 597-604.

15. Peal, S. E. (1873) The tea-bug of Assam. J. Agri. Hort. Soc. India 4, 126-132.

16. Radhakrishnan, B. (2014) Recent Advance in tea pest management. Planter Chron 10, 5-13.

17. Radhakrishnan, B., Srikumar, K. K. (2015) Pheromone trap for the management of tea mosquito bug in tea. Planter Chron. 111, 5-10.

18. Shaw, W. S. (1928) Observations on Helopeltis (Tea Mosquito Blight) for South India Tea Planters. 56 p. The Diocesan Press, Madras.

19. Srikumar, K. K., Bhat, P. S. (2013) Biology of the tea mosquito bug (Helopeltis theivora Waterhouse) on Chromolaena odorata (L.) R. M. King \& H. Rob Chil. J. Agr. Res. 73, 303-314.

20. Stonedahl, G. M. (1991) The Oriental species of Helopeltis (Heteroptera: Miridae): a review of economic literature and guide to identification. Bull. Entomol. Res. 81, 465-490.

21. Subaharan, K., Kumar, A. V. R., Prabhu, G. (2013) Electrophysiological responses of chafer beetle, Holotrichia serrata (F.) (Coleoptera: Scarabaeidae). J. Saudi Soc. Agri. Sci. 12, 155-159.

22. Sudhakaran, R. (2000) Studies on the tea mosquito bug, Helopeltis theivora Waterhouse (Hemiptera: Miridae) infesting tea in south India. PhD dissertation, Bharathiyar University, Coimbatore, India.

23. Sundararaju, D., Sundarababu, P. C. (1999) Helopeltis spp. (Heteroptera: Miridae) and their management in plantation and horticultural crops of India. J. Plant. Crop. 27, 155-174.

24. Visser, J. H., Straaten, S. V., Maarse, H. (1979) Isolation and identification of volatiles in the foliage of potato, Solanum tuberosum, a host plant of Colorado potato beetle, Leptinotarsa decemlineata. J. Chem. Ecol. 5, 13-25.

25. Wei Ming, F., JianWei, S., Rui, W., Cheng Fa, S. (2000) Electro-antennagraphic response of cotton bollworm to chemical insecticides. Plant Prot. 26, 4-6.

26. Wood-Mason, J. (1884) Report on the tea-mite and tea-bug of Assam. Taylor and Francis, London.

27. Yu, S. J. (1983) Induction of detoxifying enzymes by allelochemicals and host plants in the fall armyworm. Pest. Biochem. Physiol. 19, 330-336.

28. Yu, S. J. (1986) Host plant induction of microsomal monooxygenases in relation to organophosphate activation in fall armyworm larvae. Fla. Entomol. 69, 579-587.

29. Zeng, R. S., Zhimou, W., Goudong, N., Schular, M. A., Berenbaum, M. R. (2007) Allelochemical induction of cytochrome $\mathrm{P} 450$ mono oxygenases and amelioration of xenobiotic toxicity in Helicoverpazea. J. Chem. Ecol. 33, 449-461. 